The Effect of Nitrogen Fertilization and Fusarium culmorum Inoculation on the Biomarkers of Oxidative Stress in Wheat Flag Leaves

Utjecaj gnojidbe dušikom i inokulacije vrstom Fusarium culmorum na biomarkere oksidacijskoga stresa listova zastavičara pšenice

Matić, M., Vuković R., Vrandečić, K., Štolfa Čamagajevac I., Vuković A., Ćosić, J., Dvojković, K., Novoselović, D.

Poljoprivreda/Agriculture

ISSN: $1848-8080$ (Online)

ISSN: 1330-7142 (Print)

https://doi.org/10.18047/poljo.27.2.2

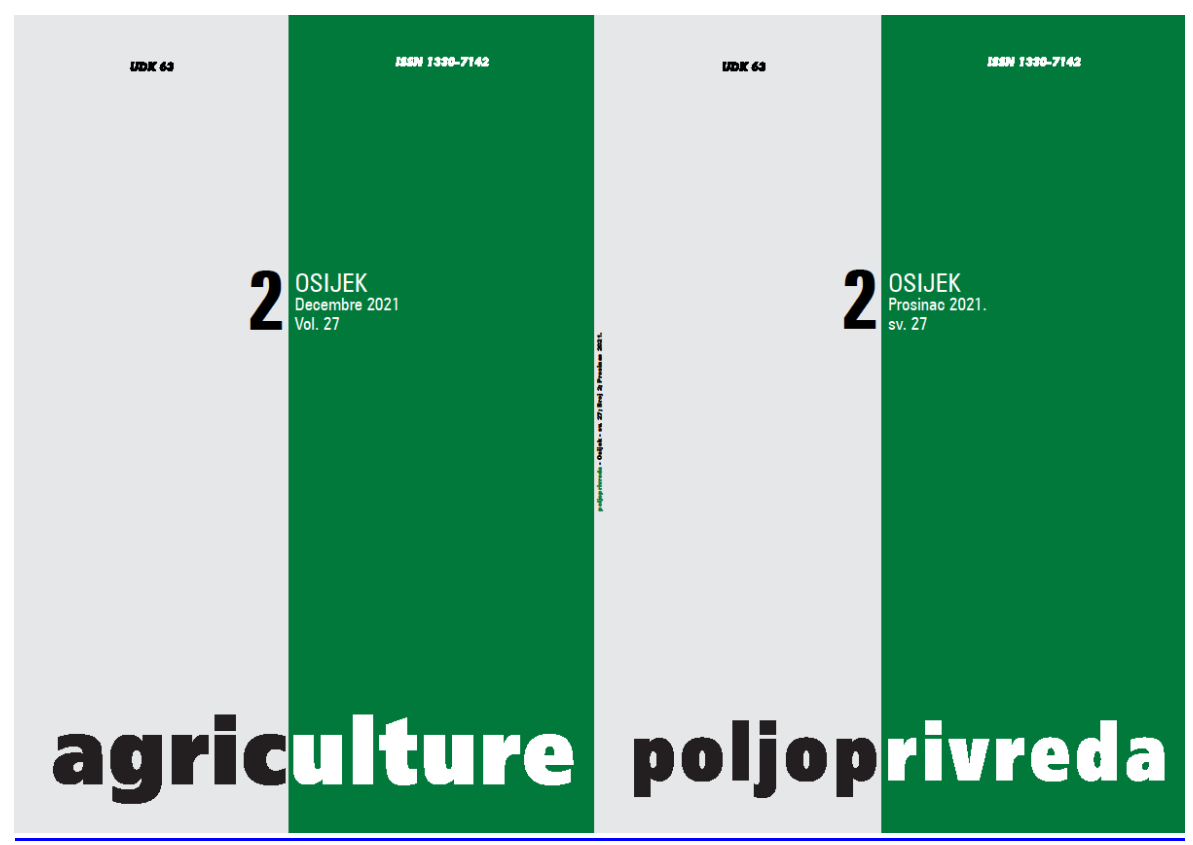

Fakultet agrobiotehničkih znanosti Osijek, Poljoprivredni institut Osijek

Faculty of Agrobiotechnical Sciences Osijek, Agricultural Institute Osijek 
ISSN 1330-7142

$U D K=633.11: 631.84$

https://doi.org/10.18047/poljo.27.2.2

\title{
THE EFFECT OF NITROGEN FERTILIZATION AND Fusarium culmorum INOCULATION ON THE BIOMARKERS OF OXIDATIVE STRESS IN WHEAT FLAG LEAVES
}

Matić, M. ${ }^{(1)}$, Vuković R. ${ }^{(2)}$, Vrandečić, K. (1), Štolfa Čamagajevac I. (2), Vuković A. ${ }^{(2)}$, Ćosić, J. (1), Dvojković, K. ${ }^{(3)}$, Novoselović, D. ${ }^{(3)}$

Original scientific paper

Izvorni znanstveni članak

\begin{abstract}
SUMMARY
During cultivation, wheat is exposed to several abiotic and/or biotic stress conditions that may adversely impact the wheat yield and quality. The impact of abiotic stress caused by nitrogen deficiency and biotic stress caused by phytopathogenic fungus Fusarium culmorum on biomarkers of oxidative stress in the flag leaf of nine winter wheat varieties (Ficko, U-1, Galloper, BC Mandica, BC Opsesija, Ingenio, Isengrain, Felix, and Bezostaya-1) was analyzed in this study. Hydrogen peroxide concentration and lipid peroxidation level were measured as indicators of oxidative stress, while the antioxidant response was determined by measuring the concentration of phenolic compounds and activities of antioxidant enzymes. Wheat variety and nitrogen treatment had a significant effect on all examined biomarkers of oxidative stress in the flag leaf, while the impact of Fusarium treatment was less pronounced. The most significant impact on the measured stress biomarkers had a low nitrogen level, which mainly increased hydrogen peroxide concentration and lipid peroxidation level and decreased activities of antioxidant enzymes in most varieties. The obtained results were discussed and compared with the previous study in which biochemical analyzes were performed on the wheat spike. There was no significant strong correlation between flag leaf and spike response in the measured parameters, which, in addition to the variety-specific response, also indicates a tissue-specific antioxidant response.
\end{abstract}

Keywords: wheat, Fusarium culmorum, nitrogen fertilization, oxidative stress, antioxidative response

\section{INTRODUCTION}

Wheat (Triticum spp.) is one of the most important cereal crops both globally and in Croatia. In the five-year period (2016-2020), the average wheat yield was $5.7 \mathrm{t}$ $\mathrm{ha}^{-1}$, which is why wheat is the grain with the highest yield in Croatia, after the corn (Statistical Yearbook of the Republic of Croatia, 2021). In field conditions, wheat is often exposed to several abiotic and/or biotic stress conditions that can significantly reduce yields.

As one of the major nutritional elements of wheat, nitrogen $(\mathrm{N})$ is essential for achieving high yields and grain quality. In winter wheat, $\mathrm{N}$ fertilization can be considered as a critical agrotechnical measure because it is almost impossible to achieve high yields and grain quality without its adequate quantity and timely application

(1) Magdalena Matić, MSc., Prof. Dr. Karolina Vrandečić, Prof. Dr. Jasenka Ćosić - Josip Juraj Strossmayer University of Osijek, Faculty of Agrobiotechnical Sciences Osijek, Vladimira Preloga 1, 31000 Osijek, Croatia, (2) Assist. Prof. Rosemary Vuković (rosemary@biologija.unios. hr), Prof. Dr. Ivna Štolfa Čamagajevac, Ana Vuković, MSc. - Josip Juraj Strossmayer University of Osijek, Department of Biology, Cara Hadrijana 8/A, 31000 Osijek, Croatia, (3) Krešimir Dvojković, Ph. D., Dario Novoselović, Ph. D. - Agricultural Institute Osijek, Južno predgrađe 17, 31000 Osijek, Croatia 
(Vukadinović and Lončarić, 1999). Adequate fertilization impacts increasing photosynthetic activity and grain protein content, resulting in higher quality and higher yields (Hawkesford, 2014). Insufficient fertilization can reduce protein synthesis resulting in lower yields and lower market price, while excessive fertilization can cause lodging and increase wheat susceptibility to various pathogens (Wagan et al., 2003). Inadequate $\mathrm{N}$ fertilization can also affect the incidence of Fusarium Head Blight (FHB), which can also cause significant economic losses in wheat production. FHB is a devastating disease of wheat caused by phytopathogenic fungi in the genus Fusarium, of which Fusarium graminearum Schwabe (Gibberella zeae Schwein. Petch.) and Fusarium culmorum (Wm. G. Sm.) Sacc. are the most common and most virulent in Croatia (Ćosić et al., 2004).

In the plant tissues exposed to various abiotic and/ or biotic stress conditions, a rapid accumulation of reactive oxygen species (ROS), such as hydrogen peroxide $\left(\mathrm{H}_{2} \mathrm{O}_{2}\right)$, superoxide radical $\left(\mathrm{O}_{2}{ }^{--}\right)$and hydroxyl radical $(\bullet \mathrm{OH})$ can occur, whose excessive amount can cause lipid peroxidation (LPO), i.e. oxidative damage to the structural components of plants (Hasanuzzaman et al., 2020). ROS can have several roles in the plant organism. They can act as reactive agents that damage cells, as signaling molecules, and they have an important role in plant pathogen defense (Demidchik, 2015; Camejo et al., 2016). In order to regulate levels of ROS and maintain redox homeostasis, plants have developed complex enzymatic and non-enzymatic antioxidant mechanisms (Apel and Hirt, 2004). The enzymatic antioxidants are enzymes such as catalase (CAT), ascorbate peroxidase $(A P X)$, glutathione reductase (GR), while the nonenzymatic antioxidants are biomolecules such as glutathione, phenols (PHE), carotenoids (Car), and others.

This study aimed to determine the effect of two different nitrogen levels and $F$. culmorum inoculation on the biomarkers of oxidative stress $\mathrm{H}_{2} \mathrm{O}_{2}, \mathrm{LPO}$, antioxidant enzymes activities, PHE, and Car) in flag leaves of nine wheat varieties. In order to establish the existence of a correlation between the antioxidant response of flag leaves and spikes, the obtained results were discussed and compared with the previous results of biochemical analyses performed under the same experimental conditions in wheat spikes (Matić et al., 2021).

\section{MATERIAL AND METHODS}

\section{Field Trial}

A field experiment with nine winter wheat varieties of different origins was conducted in 2017/2018 at the Agricultural Institute 0sijek $\left(45^{\circ} 32^{\prime} \mathrm{N}, 18^{\circ} 44^{\prime} \mathrm{E}\right)$. The experiment was set up according to the split-split plot design in three replicates. Three research factors included nine winter wheat varieties, two different nitrogen fertilization levels, and $F$. culmorum inoculation.
The winter wheat varieties included in the study were Ficko, U-1, Galloper, BC Mandica, BC Opsesija, Ingenio, Isengrain, Felix, and Bezostaya-1. Basic fertilization of $74 \mathrm{~kg} \mathrm{~N} \mathrm{ha}^{-1}, 80 \mathrm{~kg} \mathrm{P}_{2} \mathrm{O}_{5} \mathrm{ha}^{-1}$, and $120 \mathrm{~kg} \mathrm{~K}_{2} \mathrm{O} \mathrm{ha}^{-1}$ was applied by adding $100 \mathrm{~kg} \mathrm{ha}^{-1}$ of urea $(46 \% \mathrm{~N})$ and 400 $\mathrm{kg} \mathrm{ha}^{-1}$ NPK (7:20:30). The nitrogen supplementation included two different nitrogen levels: (i) without supplementation $0 \mathrm{~kg} \mathrm{~N} \mathrm{ha}^{-1}$ (low nitrogen level) and (ii) 100 $\mathrm{kg} \mathrm{N} \mathrm{ha}^{-1}$ (high nitrogen level), which was applied as top-dressings of $50 \mathrm{~kg} \mathrm{~N}^{-1}$ at tillering (Zadok's scale $23-25$ ) and $50 \mathrm{~kg} \mathrm{~N} \mathrm{ha}^{-1}$ at stem extension (Zadok's scale $33-35)$ growth stages. All cultural practices typical for commercial wheat production in Croatia (including herbicides, insecticides, and fungicides to control major weeds, insects, and foliar diseases) were used.

The method of Snijders and Van Eeuwijk (1991) was used for inoculum production. A mixture of wheat and oat grains (3:1) was left in water overnight, after which it was autoclaved and inoculated with spores of the fungus $F$. culmorum obtained from the fungal culture collection of Faculty of Agrobiotechnical Sciences Osijek, Department of Phytopathology. Inoculated grains were incubated for three weeks at $25{ }^{\circ} \mathrm{C}$, protected from sunlight. After incubation, $F$ c culmorum spores were washed off the colonized grains with sterile $\mathrm{H}_{2} \mathrm{O}$ and filtered. The final concentration of spores in the inoculum was adjusted to $1 \times 10^{6}$ spores $\mathrm{mL}^{-1}$. Spray inoculations using a motor-driven backpack-sprayer were performed primarily on wheat spikes and only on the first $\mathrm{m}^{2}$ of each plot ( $150 \mathrm{~mL}$ of suspension $\mathrm{m}^{-2}$ ). The rest of the plants on the plot are left to natural infection. Inoculations were performed individually on each plot when $50 \%$ of the plants per plot had reached anthesis (Zadoks scale 65) and were repeated after $48 \mathrm{~h}$.

\section{Determination of biomarkers of oxidative stress in flag leaves}

For measuring biomarkers of oxidative stress (oxidative/antioxidant status), wheat flag leaves were sampled seven days after inoculation. The collected samples were immediately frozen in liquid nitrogen and stored at $-80{ }^{\circ} \mathrm{C}$ until further analysis. The samples were ground into a fine powder in liquid nitrogen with a pestle and mortar. Biomarkers of oxidative stress were determined spectrophotometrically, using a UV-VIS spectrophotometer Perkin Elmer Lambda 25 (PerkinElmer, Waltham, USA). The oxidative status of wheat flag leaves was determined by measuring $\mathrm{H}_{2} \mathrm{O}_{2}$ concentration and LPO level. The $\mathrm{H}_{2} \mathrm{O}_{2}$ concentration was determined according to Mukherjee and Choudhuri (1983), where a standard curve with $\mathrm{H}_{2} \mathrm{O}_{2}$ was used for the calculation. Results were expressed in nmol of $\mathrm{H}_{2} \mathrm{O}_{2}$ per milligram of fresh weight $\left(\mathrm{nmol} \mathrm{H}_{2} \mathrm{O}_{2}\right.$ $\mathrm{mg}^{-1} \mathrm{FW}$ ). The level of LPO levels was determined by measuring the concentration of reactive substances of thiobarbituric acid (TBARS), mainly malondialdehyde 
(MDA), by the method of Verma and Dubey (2003). The amount of TBARS was calculated based on the standard curve with 1,1,3,3-tetramethoxypropane. Results were expressed in nmol of TBARS per gram of fresh weight (nmol TBARS g ${ }^{-1} \mathrm{FW}$ ).

The antioxidant response was determined spectrophotometrically by measuring the activity of the antioxidant enzymes CAT, APX, and GR. CAT activity was determined following the method of Aebi (1984). The decrease in absorbance due to the degradation of $\mathrm{H}_{2} \mathrm{O}_{2}$ was measured at $240 \mathrm{~nm}$. APX activity was determined according to Nakano and Asada (1981) with some modifications. The decrease in absorbance due to the oxidation of ascorbate was monitored at $290 \mathrm{~nm}$. GR activity was determined by the method of Halliwell and Foyer (1978), and a decrease in absorbance due to the oxidation of NADPH was monitored at $340 \mathrm{~nm}$. The specific activity of each enzyme was expressed as the amount $(\mu \mathrm{mol})$ of degraded substrate per minute per milligram of protein, i.e., as the number of units per milligram of protein $\left(\mathrm{U} \mathrm{mg}^{-1}\right.$ protein; $\mathrm{U}=\mu \mathrm{mol} \mathrm{min}^{-1}$ protein). The concentration of soluble proteins was determined using the Bradford method (1976).

As non-enzymatic biomarkers of antioxidant status, soluble phenolic content and concentrations of photosynthetic pigments were determined. The soluble phenolic content was determined by the method of Folin-Ciocalteu (Folin and Ciocalteu, 1927). A standard curve, using gallic acid as a standard, was used for the calculation. The results were expressed as microgram gallic acid equivalents (GAE) per $\mathrm{g}^{-1}$ fresh weight $(\mu \mathrm{g}$ GAE g ${ }^{-1}$ FW). Photosynthetic pigments were extracted using ice-cold acetone, and the absorbance of extracted pigments was measured at 470,645 , and $662 \mathrm{~nm}$. The extracted photosynthetic pigments' concentration was calculated according to the equations proposed by Lichtenthaler (Lichtenthaler, 1987) and expressed as mg $\mathrm{g}^{-1}$ fresh weight.

\section{Statistical Analysis}

The collected data were analyzed using the SAS Enterprise Guide 7.1 (SAS Institute Inc., Cary, NC, USA) software. The effect of the examined factors (variety, nitrogen treatment, and $F$. culmorum inoculation) on the investigated traits was determined by a three-way analysis of variance (ANOVA) ( $p \leq 0.05,0.01$, and $0.001)$. Significant differences among the treatments in each variety separately were determined using the Fisher LSD test $(p \leq 0.05)$.

\section{RESULTS AND DISCUSSION}

Tolerance to stressful conditions can be increased by using various treatments to enhance the plant's defense response or by growing varieties more resistant to adverse environmental effects. This study analyzed the effect of abiotic stress caused by nitrogen deficiency and biotic stress caused by phytopathogenic fungus F. culmorum on the biomarkers of oxidative stress in flag leaves of nine winter wheat varieties. Wheat variety, nitrogen treatment, and inoculation with $F$. culmorum significantly impacted the examined biomarkers of oxidative stress in flag leaves. Furthermore, the results are discussed in the context of a previously published study where, under the same experimental conditions, the same analyzes were performed on the wheat spikes (Matić et al., 2021), which are most commonly used in biochemical analyzes of the FHB infection impact. Although FHB occurs primarily on wheat spikes, spike infection can cause changes in some metabolic pathways in other plant organs, e.g., changes in the rate of flag leaf photosynthesis (Yang et al., 2016; Španić et al., 2017a). In this study, we wanted to determine whether the spikes infection also reflects on the antioxidant response of flag leaves and whether there is a correlation in the antioxidant response between wheat flag leaves and spikes. Although a correlation between measured biochemical parameters could allow the use of flag leaves for a detailed analysis of oxidative stress caused by FHB, the results of this study did not show a significantly strong correlation between flag leaves and spikes in measured parameters (Pearson correlation test results not shown). The antioxidant response was both variety- and tissue-specific.

Three-way ANOVA revealed a significant variety effect on all examined biomarkers of oxidative stress in wheat flag leaves (Table 1). Under the same experimental conditions, an equally significant variety effect on biomarkers of oxidative stress was found in wheat spikes (Matić et al., 2021). Nitrogen treatment significantly affected the concentration of $\mathrm{H}_{2} \mathrm{O}_{2}$, PHE content, and the activity of antioxidant enzymes CAT, APX, and GR. Inoculation with $F$. culmorum isolate significantly affected the concentration of $\mathrm{H}_{2} \mathrm{O}_{2}$ and TBARS and PHE content $(p \leq 0.001)$. In contrast to wheat flag leaves, $F$. culmorum inoculation of wheat spikes affected most of the measured biomarkers of oxidative stress (PHE, CAT, $\mathrm{GR}$, Car). The interaction between the three main factors was significant for all examined biomarkers except for PHE content. 
Table 1. Three-way ANOVA of the influence of variety, nitrogen treatment, and Fusarium culmorum inoculation and their interactions on the examined biomarkers of oxidative stress in the flag leaf of wheat

Tablica 1. Trofaktorijalna analiza varijanca (ANOVA) utjecaja sorte, tretmana dušikom i inokulacije vrstom Fusarium culmorum i njihovih interakcija na ispitivane biomarkere oksidacijskoga stresa u listu zastavičaru pšenice

\begin{tabular}{|l|c|c|c|c|c|c|c|}
\hline \multicolumn{7}{|c|}{ Mean sum of squares / Srednja suma kvadrata } \\
\hline $\begin{array}{l}\text { Source of Variation / } \\
\text { Izvor variranja }\end{array}$ & $\begin{array}{l}\text { Degrees of freedom } \\
\text { Stupnjevi slobode }\end{array}$ & HP & TBARS & PHE & CAT & APX & GR \\
\hline $\begin{array}{l}\text { Variety (V)/ } \\
\text { Sorta }\end{array}$ & 8 & $95.36^{* * *}$ & $99.96^{* * *}$ & $2115.80^{* * *}$ & $1300.17^{*}$ & $0.29^{* * *}$ & $787.75^{* * *}$ \\
\hline $\begin{array}{l}\text { Nitrogen treatment (N)/ } \\
\text { Tretman dušikom }\end{array}$ & 1 & $50.63^{* * *}$ & $3.53 \mathrm{~ns}$ & $2199.62^{* * *}$ & $19041.20^{* * *}$ & $0.13^{*}$ & $3764.30^{* * *}$ \\
\hline $\begin{array}{l}\text { Fusarium inoculation (F)/ } \\
\text { Fusarium inokulacija }\end{array}$ & 1 & $47.00^{* * *}$ & $65.25^{* * *}$ & $422.01^{* * *}$ & $1491.89 \mathrm{~ns}$ & $0.04 \mathrm{~ns}$ & $421.11 \mathrm{~ns}$ \\
\hline V $\times \mathrm{N}$ & 8 & $11.85^{* * *}$ & $9.97^{* * *}$ & $40.39 \mathrm{~ns}$ & $1598.01^{* *}$ & $0.16^{* * *}$ & $124.06 \mathrm{~ns}$ \\
\hline $\mathrm{V} \times \mathrm{F}$ & 8 & $8.87^{* * *}$ & $10.32^{* * *}$ & $77.31^{*}$ & $1480.71^{* *}$ & $0.04 \mathrm{~ns}$ & $70.60 \mathrm{~ns}$ \\
\hline $\mathrm{N} \times \mathrm{F}$ & 1 & $10.41^{* *}$ & $1.67 \mathrm{~ns}$ & $53.49 \mathrm{~ns}$ & $1306.70 \mathrm{~ns}$ & $0.07 \mathrm{~ns}$ & $2.11 \mathrm{~ns}$ \\
\hline $\mathrm{V} \times \mathrm{N} \times \mathrm{F}$ & 8 & $5.11^{* * *}$ & $9.97^{* * *}$ & $48.36 \mathrm{~ns}$ & $1899.69^{* * *}$ & $0.10^{* * *}$ & $221.61^{*}$ \\
\hline
\end{tabular}

ns - not significant/nije statistički značajno; ${ }^{*},{ }^{* *}$ and ${ }^{* * *}$ - significant at the level of probability $p \leq 0.05,0.01$, and $0.001 /$ značajno na razini $p \leq 0,05,0,01$ 0,001. HP, hydrogen peroxide/vodik peroksid; TBARS, thiobarbituric acid reactive substances/reaktivne supstance tiobarbiturne kiseline; PHE, phenolics/fenoli; CAT, catalase/katalaza; APX, ascorbate peroxidase/askorbat-peroksidaza; GR, glutathione reductase/glutation-reduktaza.

In the U-1, Galloper, and BC Opsesija varieties, at low nitrogen level, $F$. culmorum inoculation caused an increase in $\mathrm{H}_{2} \mathrm{O}_{2}$ concentration, while at high nitrogen level, $\mathrm{H}_{2} \mathrm{O}_{2}$ concentration was increased in the Galloper, BC Mandica, BC Opsesija, Felix, and Bezostaya-1 varieties (Figure 1a). In most non-inoculated varieties, low nitrogen level tended to increase $\mathrm{H}_{2} \mathrm{O}_{2}$ concentration, and a significant increase was found in the Ficko, U-1, $B C$ Opsesija, Ingenio, and Bezostaya-1 varieties. Since the lack of nitrogen supplementation in non-inoculated plants mainly caused an increase in TBARS content and a decrease in the activity of antioxidant enzymes, $\mathrm{H}_{2} \mathrm{O}_{2}$ could act as a promoter of oxidative stress. Mamenko (2018) also found an increase in the concentration of $\mathrm{H}_{2} \mathrm{O}_{2}$ in wheat leaves under an insufficient supply of soil nitrogen. However, the author also found an increase in the activity of antioxidant enzymes and concluded that $\mathrm{H}_{2} \mathrm{O}_{2}$ acted as a signaling molecule that affects the activation of wheat defense mechanisms under insufficient nitrogen supply.
Numerous studies have shown that different abiotic and/or biotic stress conditions can induce LPO, which can cause oxidative damage to the structural components of plants (Španić et al., 2017b; Hasanuzzaman et al., 2020). The occurrence of LPO caused by pathogen attack and/or insufficient nitrogen fertilization was also found in some varieties in this study. In the Ficko, BC Opsesija, and Bezostaya-1 varieties at low nitrogen level, inoculation with $F$. culmorum caused an increase in TBARS content (Figure 1b). In contrast, the TBARS content was increased at high nitrogen level in the Galloper, BC Opsesija, and Ingenio varieties. On average, nitrogen treatment itself did not cause any significant changes in TBARS content in wheat flag leaves (Table 1). However, low nitrogen level caused an increase in TBARS content in non-inoculated varieties $B C$ Opsesija, Ingenio, and Isengrain. Although the level of LPO is variety and tissue-specific, the increase in LPO is more pronounced in flag leaves than wheat spikes, i.e., it is present in a much larger number of varieties at different treatments (Matić et al., 2021). 

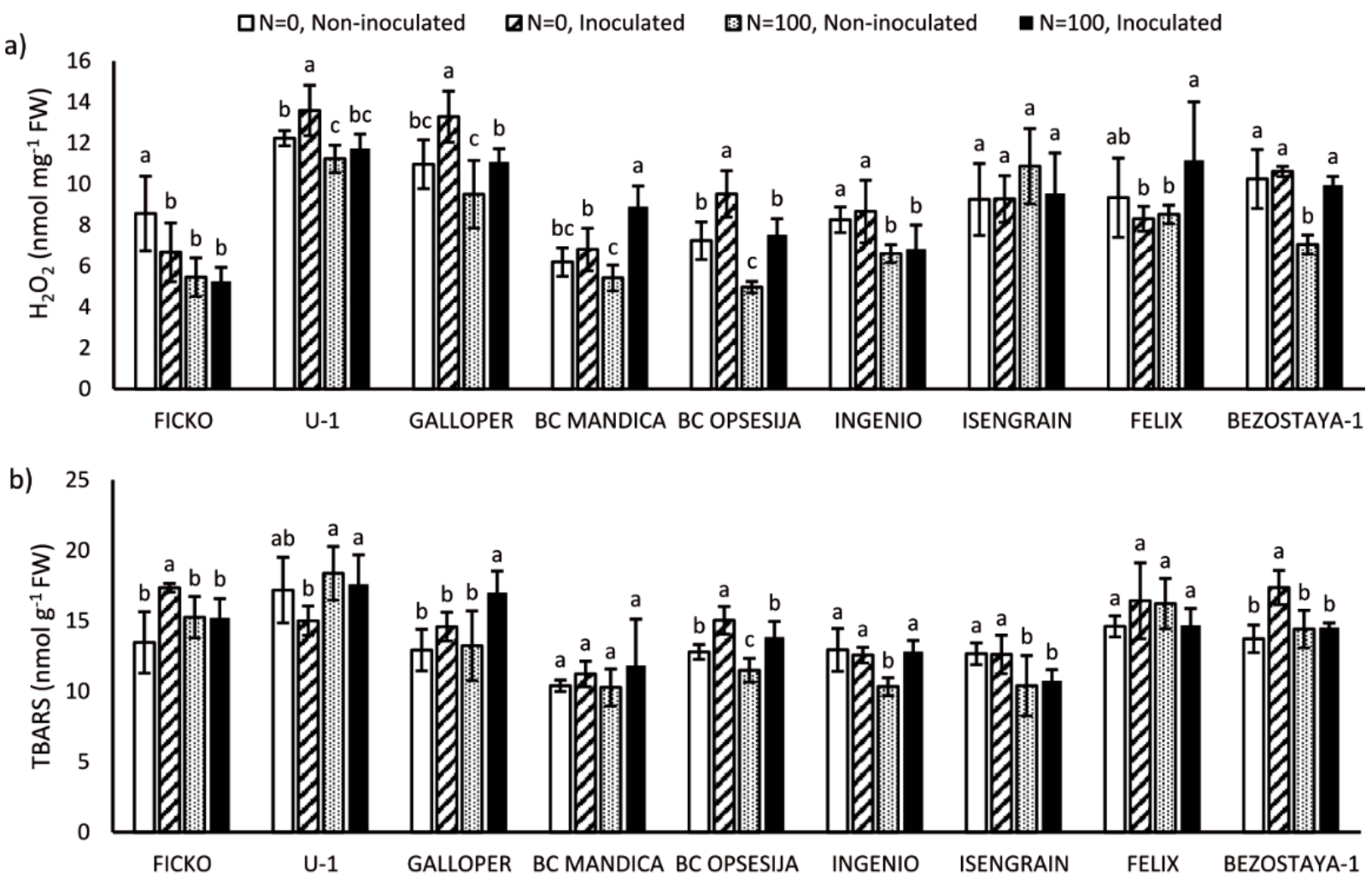

Figure 1. Hydrogen peroxide $\left(\mathrm{H}_{2} \mathrm{O}_{2} ;\right.$ a) and thiobarbituric acid reactive substances (TBARS; b) content in flag leaves of nine wheat varieties under different nitrogen $\left(0 \mathrm{~kg} \mathrm{~N} \mathrm{ha}^{-1}\right.$ and $\left.100 \mathrm{~kg} \mathrm{~N} \mathrm{ha}^{-1}\right)$ and Fusarium culmorum (non-inoculated and inoculated) treatments. Values are means of six replicates \pm standard deviation (SD). Different letters above the bars indicate significant differences according to Fisher's LSD test $(p \leq 0.05)$ among different treatments in each variety separately.

Grafikon 1. Koncentracija vodika peroksida $\left(\mathrm{H}_{2} \mathrm{O}_{2} ;\right.$ a) $i$ količina reaktivnih supstanci tiobarbiturne kiseline (TBARS; $\left.b\right)$ listova zastavičara devet sorata pšenice pri različitim prihranama dušikom $\left(0 \mathrm{~kg} \mathrm{~N} \mathrm{ha}^{-1}\right.$ i $\left.100 \mathrm{~kg} \mathrm{~N} \mathrm{ha}^{-1}\right)$ i tretmanom Fusarium culmorum (neinokulirane i inokulirane biljke). Rezultati su prikazani kao srednja vrijednost šest replika \pm standardna devijacija. Različita slova iznad pojedinoga stupca označavaju statistički značajne razlike između tretmana u svakoj sorti pojedinačno, prema Fisherovu LSD testu $(p \leq 0,05)$.

The PHE content was significantly influenced by all three main factors, nitrogen treatment, variety, and F. culmorum inoculation $(\mathrm{p} \leq 0.001)$ (Table 1). The most significant effect had a nitrogen treatment itself, and on average, a low nitrogen level caused an increase of $8.82 \%$ in the PHE content compared to a high nitrogen level. Inoculation with $F$. culmorum isolate caused an increase in the PHE content in the Galloper and $B C$ Opsesija varieties at low nitrogen level (Figure 2). The trend of increasing PHE content due to $F$. culmorum inoculation was also observed at a high nitrogen level, and a significant increase was found in the $B C$ Mandica, $B C$ Opsesija, and Bezostaya-1 varieties. In most non-inoculated varieties, low nitrogen level tended to increase PHE content, although a significant increase was found in the Ficko, Galloper, BC Mandica, BC Opsesija, and Bezostaya-1 varieties. The obtained results are in accordance with other studies in which it was found that under conditions of nitrogen deficiency, due to the increase of $\mathrm{C}: \mathrm{N}$ ratio within plants, there is an increased formation and accumulation of phenolic compounds (Ibrahim et al., 2011; Munene et al., 2017; Deng et al., 2019). Phenolic compounds are the most significant and widespread plant secondary metabolites that play an important role in plant defense mechanisms under abiotic and/or biotic stress conditions (Kulbat, 2016; Sharma et al., 2019). Therefore, nitrogen fertilization is of great importance because it can affect primary and secondary plant metabolites (Chen et al., 2011). In the research of Matić et al. (2021), growing wheat at a low nitrogen level caused a decrease in the PHE content in wheat spikes of non-inoculated plants, suggesting a tissue-specific wheat response. 


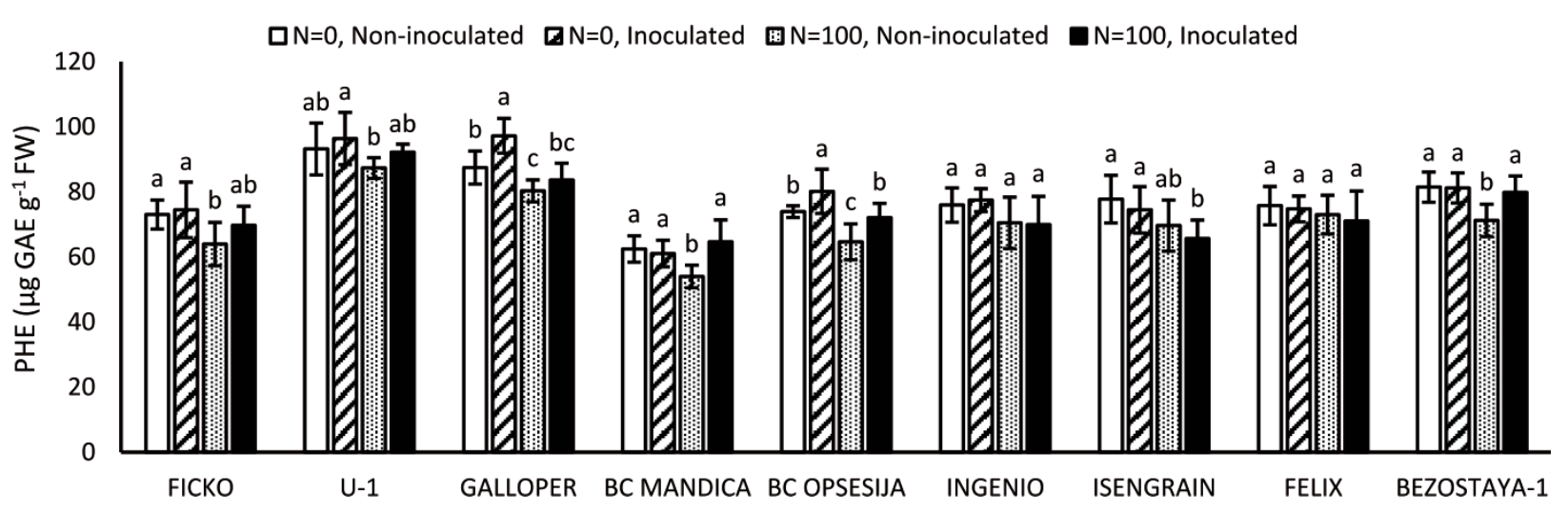

Figure 2. Soluble phenolics (PHE) content in flag leaves of nine wheat varieties under different nitrogen $10 \mathrm{~kg} \mathrm{~N}$ $\mathrm{ha}^{-1}$ and $100 \mathrm{~kg} \mathrm{~N} \mathrm{ha}^{-1}$ ) and Fusarium culmorum (non-inoculated and inoculated) treatments. Values are means of six replicates \pm standard deviation (SD). Different letters above the bars indicate significant differences according to Fisher's LSD test $(\mathbf{p} \leq \mathbf{0 . 0 5})$ among different treatments in each variety separately.

Grafikon 2. Koncentracija topljivih fenola (PHE) listova zastavičara devet sorata pšenice pri različitim prihranama dušikom $\left(0 \mathrm{~kg} \mathrm{~N} \mathrm{ha}^{-1}\right.$ i $100 \mathrm{~kg} \mathrm{~N} \mathrm{ha-1}$ ) i tretmanom vrstom Fusarium culmorum (neinokulirane i inokulirane biljke). Rezultati su prikazani kao srednja vrijednost šest replika \pm standardna devijacija. Različita slova iznad pojedinoga stupca označavaju statistički značajne razlike između tretmana u svakoj sorti pojedinačno, prema Fisherovu LSD testu $(p \leq 0,05)$.

Nitrogen treatment and wheat variety significantly affected the antioxidant enzymes CAT, APX, and GR (Table 1). On average, compared to high levels, a low nitrogen level caused a decrease in the activity of the antioxidant enzymes CAT and GR in wheat flag leaves. The decrease in antioxidant enzyme activity was $9.21 \%$ for CAT and $7.63 \%$ for GR, respectively. On average, F. culmorum inoculation did not significantly affect the activity of antioxidant enzymes in wheat flag leaves (Table 1). However, analysis of the effect of $F$. culmorum inoculation, in each variety separately, showed significant changes in enzymes activity, which were variety-specific (Figure 3). Inoculation with $F$. culmorum isolate caused an increase in CAT activity in the Ficko variety at low nitrogen level, while in the $B C$ Opsesija and Felix varieties CAT activity was decreased (Figure 3a). In conditions of high nitrogen level, inoculation with F. culmorum isolate caused an increase in CAT activity in the Bezostaya-1 variety and a decrease in CAT activity in the Ingenio variety. At low nitrogen level, inoculation with $F$. culmorum isolate caused an increase in APX activity in the $B C$ Opsesija and Isengrain varieties, while in conditions of high nitrogen level, APX activity was increased in the Ficko variety (Figure 3b). Inoculation with $F$ culmorum isolate tended to decrease GR activity in almost all varieties at both nitrogen levels. However, a significant decrease in GR activity was found in the Ingenio variety at a low nitrogen level and the Felix variety at a high nitrogen level (Figure 3c). In addition to the fact that the response of antioxidant enzymes to $F$. culmorum inoculation depended on the variety, a comparison of the results of this analysis with previous analysis in wheat spikes (Matić et al., 2021) suggest a tissue-specific response. In the non-inoculated varieties Ficko, U-1, Galloper, and Ingenio, low nitrogen level decreased the CAT activity, while in the variety Isengrain decreased the APX activity. Also, compared to the high nitrogen level, the low nitrogen level caused a trend of decreasing GR activity in almost all non-inoculated varieties, although a significant decrease in GR activity was found only in the Felix variety. According to Matić et al. (2021), insufficient nitrogen supplementation caused a decrease in the activity of antioxidant enzymes in wheat spikes of most non-inoculated varieties. Decreased activity of antioxidant enzymes in conditions of nitrogen deficiency may be associated with reduced amino acids and protein synthesis in conditions of low nitrogen supply. 

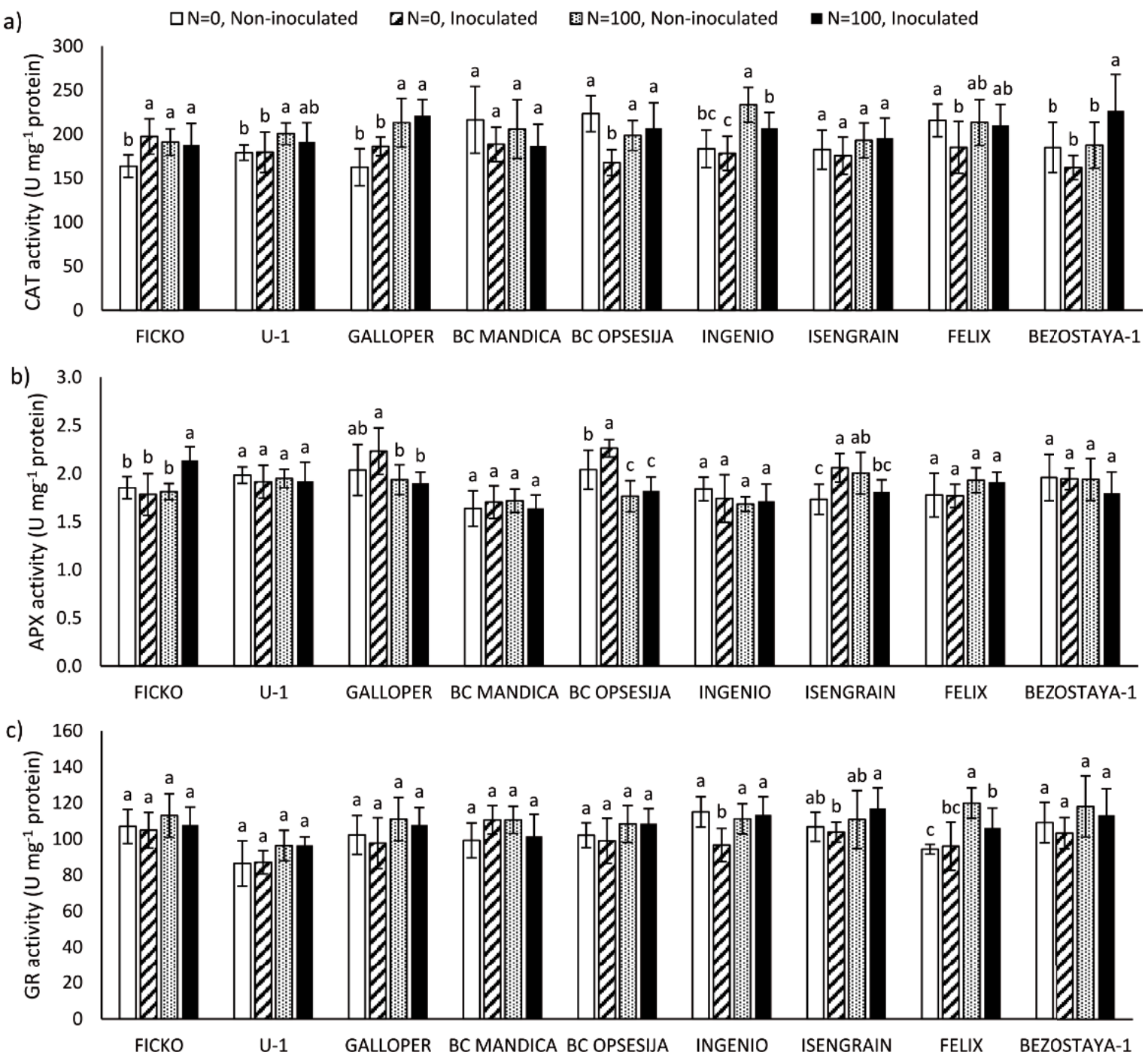

Figure 3. Antioxidant enzyme activities: catalase (CAT; a), ascorbate peroxidase (APX; b), and glutathione reductase (GR; $c)$ in flag leaves of nine wheat varieties under different nitrogen $\left(0 \mathrm{~kg} \mathrm{~N} \mathrm{ha} \mathrm{a}^{-1}\right.$ and $\left.100 \mathrm{~kg} \mathrm{~N} \mathrm{ha}^{-1}\right)$ and Fusarium culmorum (non-inoculated and inoculated) treatments. Values are means of six replicates \pm standard deviation (SD). Different letters above the bars indicate significant differences according to Fisher's LSD test ( $p \leq$ 0.05) among different treatments in each variety separately.

Grafikon 3. Aktivnosti antioksidacijskih ezima: katalaze (CAT; a), askorbat-peroksidaze (APX; b) i glutation-reduktaze (GR; c) listova zastavičara devet sorata pšenice pri različitim prihranama dušikom $\left(0 \mathrm{~kg} \mathrm{~N} \mathrm{ha}^{-1}\right.$ i $\left.100 \mathrm{~kg} \mathrm{~N} \mathrm{ha-1}\right)$ i različitim tretmanom vrstom Fusarium culmorum (neinokulirane i inokulirane biljke). Rezultati su prikazani kao srednja vrijednost šest replika \pm standardna devijacija. Različita slova iznad pojedinoga stupca označavaju statistički značajne razlike između tretmana u svakoj sorti pojedinačno, prema Fisherovu LSD testu $(p \leq 0,05)$.

Three-way ANOVA revealed a significant variety and nitrogen treatment effects on the content of photosynthetic pigments in wheat flag leaves $(p \leq 0.001$; Table 2). On the other hand, inoculation with F. culmorum isolate had no significant effect on the content of photosynthetic pigments in wheat flag leaves (Table 2), while its effect was significant in the wheat spikes (Matić et al., 2021). In their study of a large number of wheat genotypes, Molero and Reynolds (2020) observed a lack of correlation between flag leaves and spikes photosynthesis, suggesting their independence.

On average, a low nitrogen level decreased $\mathrm{Chl} \mathrm{a,}$ $\mathrm{Chl} \mathrm{b}, \mathrm{Chl} a+b$, and Car content in wheat flag leaves, compared to high nitrogen level. Decreased content of photosynthetic pigments under limited nitrogen conditions was also found in wheat spikes (Matić et al., 2021). As a macronutrient, nitrogen is an integral part of cells, proteins, nucleic acids, enzymes, and photosynthetic pigments of plants. Nitrogen deficiency during the growing season can cause a decrease in the content of photosynthetic pigments, which in turn can cause inhibition of photosynthesis and reduction of photosynthetic capacity (Boussadia et al., 2010; Prinsi et al., 2020). Reduced photosynthetic capacity, in turn, can negatively affect crop yield and quality. 
Table 2. Three-way ANOVA of the influence of variety, nitrogen treatment, and Fusarium culmorum inoculation and their interactions on the content of chloroplast pigments in the flag leaf of wheat

Tablica 2. Trofaktorijalna analiza varijanca (ANOVA) utjecaja sorte, tretmana dušikom i inokulacije izolatom Fusarium culmorum i njihovih interakcija na sadržaj kloroplastnih pigmenata u listu zastavičaru pšenice

\begin{tabular}{|l|c|c|c|c|c|}
\hline \multicolumn{5}{|c|}{ Mean sum of squares / Srednja suma kvadrata } \\
\hline $\begin{array}{l}\text { Source of Variation / } \\
\text { Izvor variranja }\end{array}$ & $\begin{array}{c}\text { Degrees of freedom / } \\
\text { Stupnjevi slobode }\end{array}$ & Chl a & Chl b & Chl a $+\mathrm{b}$ & Car \\
\hline $\begin{array}{l}\text { Variety (V)/ } \\
\text { Sorta }\end{array}$ & 8 & $0.1836^{* * *}$ & $0.0297^{* * *}$ & $0.3547^{* * *}$ & $0.0090^{* *}$ \\
\hline $\begin{array}{l}\text { Nitrogen treatment (N) / } \\
\text { Tretman dušikom }\end{array}$ & 1 & $1.7471^{* * *}$ & $0.3130^{* * *}$ & $3.5392^{* * *}$ & $0.0966^{* * *}$ \\
\hline $\begin{array}{l}\text { Fusarium inoculation (F) / } \\
\text { Fusarium inokulacija }\end{array}$ & 1 & $0.0004 \mathrm{~ns}$ & $0.0012 \mathrm{~ns}$ & $0.0031 \mathrm{~ns}$ & $0.0013 \mathrm{~ns}$ \\
\hline V $\times \mathrm{N}$ & 8 & $0.0279 \mathrm{~ns}$ & $0.0053 \mathrm{~ns}$ & $0.0483 \mathrm{~ns}$ & $0.0025 \mathrm{~ns}$ \\
\hline V $\times \mathrm{F}$ & 8 & $0.0441 \mathrm{~ns}$ & $0.0088 \mathrm{~ns}$ & $0.0904 \mathrm{~ns}$ & $0.0040 \mathrm{~ns}$ \\
\hline $\mathrm{N} \times \mathrm{F}$ & 1 & $0.0239 \mathrm{~ns}$ & $0.0063 \mathrm{~ns}$ & $0.0547 \mathrm{~ns}$ & $0.0035 \mathrm{~ns}$ \\
\hline $\mathrm{V} \times \mathrm{N} \times \mathrm{F}$ & 8 & $0.0057 \mathrm{~ns}$ & $0.0046 \mathrm{~ns}$ & $0.0143 \mathrm{~ns}$ & $0.0009 \mathrm{~ns}$ \\
\hline
\end{tabular}

ns - not significant/nije statistički značajno; ${ }^{*},{ }^{* *}$ and ${ }^{* * *}$ - significant at the level of probability $\mathrm{p} \leq 0.05,0.01$, and $0.001 / \mathrm{značajno}$ na razini $\mathrm{p} \leq 0,05,0,01 \mathrm{i} 0,001$. Chl a, chlorophyll a/klorofil a; Chl b, chlorophyll b/klorofil b; Chl a+b, total chlorophyll/ukupni klorofil; Car, carotenoids/karotenoidi.

\section{CONCLUSION}

Wheat variety and nitrogen treatment significantly affected all measured biomarkers of oxidative stress in the flag leaves, while the effect of $F$. culmorum treatment was less pronounced. The most significant effect on the measured biomarkers had a low nitrogen level itself, where a trend of increased $\mathrm{H}_{2} \mathrm{O}_{2}$ concentration and LPO level, and decreased activities of antioxidant enzymes was observed in most varieties. The obtained results were discussed and compared with the previous results of biochemical analyses performed under the same experimental conditions in wheat spikes. There was no significantly strong correlation between flag leaves and spikes in the measured parameters, which, in addition to the variety-specific response, also indicates a tissuespecific antioxidant response.

\section{ACKNOWLEDGEMENTS}

This work was funded by the grant of the Croatian Science Foundation IP-2016-06-2178 and the EU project KK.01.1.1.01.0005 Biodiversity and Molecular Plant Breeding, Centre of Excellence for Biodiversity and Molecular Plant Breeding (CoE CroP-BioDiv), Zagreb, Croatia.

\section{REFERENCES}

1. Aebi, H. (1984). Catalase in vitro. Methods in enzymology, 105, 121-126.

2. Apel, K., \& Hirt, H. (2004). Reactive oxygen species: metabolism, oxidative stress, and signal transduction. Annual Review of Plant Biology, 55, 373-399. doi: 10.1146/annurev.arplant.55.031903.141701

3. Boussadia, 0., Steppe, K., Zgallai, H., El Hadj, S. B., Braham, M., Lemeur, R., \& Van Labeke, M. C. (2010). Effects of nitrogen deficiency on leaf photosynthesis, carbohydrate status and biomass production in two olive cultivars 'Meski'and 'Koroneiki'. Scientia Horticulturae, 123(3), 336-342. doi: 10.1016/j.scienta.2009.09.023

4. Bradford, M. M. (1976). A rapid and sensitive method for the quantitation of microgram quantities of protein utilizing the principle of protein-dye binding. Analytical biochemistry, 72(1-2), 248-254.

doi: 10.1006/abio.1976.9999

5. Camejo, D., Guzmán-Cedeño, Á., \& Moreno, A. (2016). Reactive oxygen species, essential molecules, during plant-pathogen interactions. Plant Physiology and Biochemistry, 103, 10-23.

doi: 10.1016/j.plaphy.2016.02.035

6. Chen, L., Liu, O. O., Gai, J. Y., Zhu, Y. L., Yang, L. F., \& Wang, C. (2011). Effects of nitrogen forms on the growth and polyamine contents in developing seeds of vegetable soybean. Journal of plant nutrition, 34(4), 504-521. doi: 10.1080/01904167.2011.538113

7. Ćosić, J., Vrandečić, K., \& Svitlica, B. (2004). Fusarium vrste izolirane s pšenice i kukuruza u istočnoj Hrvatskoj. Poljoprivreda, 10(1), 5-8. 
8. Demidchik, V. (2015). Mechanisms of oxidative stress in plants: from classical chemistry to cell biology. Environmental and experimental botany, 109, 212-228. doi: 10.1016/j.envexpbot.2014.06.021

9. Deng, B., Li, Y., Xu, D., Ye, O., \& Liu, G. (2019). Nitrogen availability alters flavonoid accumulation in Cyclocarya paliurus via the effects on the internal carbon/nitrogen balance. Scientific reports, 9(1), 1-9. doi: 10.1038/s41598-019-38837-8

10. Folin, 0., \& Ciocalteu, V. (1927). On tyrosine and tryptophane determinations in proteins. Journal of biological chemistry, 73(2), 627-650.

11. Halliwell, B., \& Foyer, C. H. (1978). Properties and physiological function of a glutathione reductase purified from spinach leaves by affinity chromatography. Planta, 139(1), 9-17. doi: 10.1007/BF00390803

12. Hasanuzzaman, M., Bhuyan, M. H. M. B., Zulfiqar, F., Raza, A., Mohsin, S. M., Mahmud, J. A., Fujita, M., \& Fotopoulos, V. (2020). Reactive oxygen species and antioxidant defense in plants under abiotic stress: Revisiting the crucial role of a universal defense regulator. Antioxidants, 9(8), 681. doi: 10.3390/antiox9080681

13. Hawkesford, M. J. (2014). Reducing the reliance on nitrogen fertilizer for wheat production. Journal of cereal science, 59(3), 276-283. doi: 10.1016/j.jcs.2013.12.001

14. Ibrahim, M. H., Jaafar, H. Z., Rahmat, A., \& Rahman, Z. A. (2011). Effects of nitrogen fertilization on synthesis of primary and secondary metabolites in three varieties of kacip fatimah (Labisia pumila Blume). International journal of molecular sciences, 12(8), 5238-5254. doi: 10.3390/ijms12085238

15. Kulbat, K. (2016). The role of phenolic compounds in plant resistance. Biotechnology and Food Science, 80, 97-108.

16. Lichtenthaler, H. K. (1987). Chlorophylls and carotenoids: pigments of photosynthetic biomembranes. Methods in enzymology, 148, 350-382. doi: $10.1016 / 0076-6879(87) 48036-1$

17. Mamenko, T. P. (2018). Activation of antioxidant enzymes and content of hydrogen peroxide in winter wheat leaves by deficit of soil nitrogen. Ukrainian Journal of Ecology, 8(1). doi: 10.15421/2018_199

18. Matić, M., Vuković, R., Vrandečić, K., Štolfa Čamagajevac, I., Ćosić, J., Vuković, A., Sabljić, K., Sabo, N., Dvojković, K., Novoselović, D. (2021). Oxidative Status and Antioxidative Response to Fusarium Attack and Different Nitrogen Levels in Winter Wheat Varieties. Plants, 10(4), 611. doi: 10.3390/plants10040611

19. Molero, G., \& Reynolds, M. P. (2020). Spike photosynthesis measured at high throughput indicates genetic variation independent of flag leaf photosynthesis. Field Crops Research, 255, 107866. doi: 10.1016/j.fcr.2020.107866

20. Mukherjee, S. P., \& Choudhuri, M. A. (1983). Implications of water stress-induced changes in the levels of endogenous ascorbic acid and hydrogen peroxide in Vigna seedlings. Physiologia plantarum, 58(2), 166-170. doi: 10.1111/j.1399-3054.1983.tb04162.x
21. Munene, R., Changamu, E., Korir, N., \& Joseph, G. O. (2017). Effects of different nitrogen forms on growth, phenolics, flavonoids and antioxidant activity in amaranth species. Tropical Plant Research, 4(1), 81-89. doi: 10.22271/tpr.2017.v4.i1.012

22. Nakano, Y., \& Asada, K. (1981). Hydrogen peroxide is scavenged by ascorbate-specific peroxidase in spinach chloroplasts. Plant and cell physiology, 22(5), 867-880. doi: 10.1093/oxfordjournals.pcp.a076232

23. Prinsi, B., Negrini, N., Morgutti, S., \& Espen, L. (2020). Nitrogen starvation and nitrate or ammonium availability differently affect phenolic composition in green and purple basil. Agronomy, 10(4), 498. doi: 10.3390/agronomy 10040498

24. Sharma, A., Shahzad, B., Rehman, A., Bhardwaj, R. Landi, M., \& Zheng, B. (2019). Response of phenylpropanoid pathway and the role of polyphenols in plants under abiotic stress. Molecules, 24(13), 2452. doi: 10.3390/molecules24132452

25. Snijders, C. H. A., \& Van Eeuwijk, F. A. (1991). Genotype $x$ strain interactions for resistance to Fusarium head blight caused by Fusarium culmorum in winter wheat. Theoretical and Applied Genetics, 81(2), 239-244. doi: 10.1007/BF00215729

26. Statistički ljetopis Republike Hrvatske (2021). Državni zavod za statistiku Republike Hrvatske. Zagreb.

27. Španić, V., Viljevac Vuletić, M., Drezner, G., Zdunić, Z., \& Horvat, D. (2017a). Performance indices in wheat chlorophyll a fluorescence and protein quality influenced by FHB. Pathogens, 6(4), 59. doi: 10.3390/pathogens6040059

28. Španić, V., Vuletić, M. V., Abičić, I., \& Marček, T. (2017b). Early response of wheat antioxidant system with special reference to Fusarium head blight stress. Plant Physiology and Biochemistry, 115, 34-43. doi: 10.1016/j.plaphy.2017.03.010

29. Verma, S., \& Dubey, R. S. (2003). Lead toxicity induces lipid peroxidation and alters the activities of antioxidant enzymes in growing rice plants. Plant Science, 164(4), 645-655. doi: 10.1016/S0168-9452(03)00022-0.

30. Vukadinović, V., Lončarić, Z. (1999). Ishrana bilja. Poljoprivredni fakultet Sveučilišta u Osijeku, Osijek.

31. Wagan, M. R., Oad, F. C., \& Nenwani, K. S. (2003). Quantitative and Qualitative Characters of Wheat Crop Under Various Sources and Methods of Nitrogenous Fertilizer Application. Asian Journal of Plant Sciences, 2(9), 683-687. doi: 10.3923/ajps.2003.683.687

32. Yang, S., Li, X., Chen, W., Liu, T., Zhong, S., Ma, L., Zhang, M., Zhang, H., Yu, D., \& Luo, P. (2016). Wheat resistance to fusarium head blight is associated with changes in photosynthetic parameters. Plant disease, 100(4), 847-852. doi: 10.1094/PDIS-04-14-0398-RE 


\section{UTJECAJ GNOJIDBE DUŠIKOM I INOKULACIJE VRSTOM Fusarium culmorum NA BIOMARKERE OKSIDACIJSKOGA STRESA LISTOVA ZASTAVIČARA PŠENICE}

\section{SAŽETAK}

Pri uzgoju je pšenica izložena brojnim abiotičkim i/ili biotičkim stresnim čimbenicima koji mogu negativno djelovati na prinos $i$ kvalitetu. $U$ ovome je radu analiziran utjecaj abiotičkoga stresa uzrokovanog deficitom dušika i biotičkoga stresa izazvanog fitopatogenom gljivom Fusarium culmorum na biomarkere oksidacijskoga stresa u listu zastavičaru devet sorata ozime pšenice (Ficko, U-1, Galloper, BC Mandica, BC Opsesija, Ingenio, Isengrain, Felix i Bezostaya-1). Kao pokazatelji oksidacijskoga stresa mjereni su koncentracija vodikova peroksida $i$ razina lipidne peroksidacije, dok je antioksidacijski odgovor određen mjerenjem koncentracije fenolnih spojeva $i$ aktivnosti antioksidacijskih enzima. Sorta pšenice $i$ tretman dušikom imali su značajan utjecaj na sve ispitivane biomarkere oksidacijskoga stresa u listu zastavičaru, dok je utjecaj tretmana gljivom Fusarium bio manje izražen. Najznačajniji utjecaj na mjerene pokazatelje stresa imao je uzgoj u uvjetima niske razine dušika, pri čemu je u većini sorata vidljiv trend povećanja koncentracije vodikova peroksida $i$ razine lipidne peroksidacije te smanjenja aktivnosti antioksidacijskih enzima. Dobiveni su rezultati prokomentirani i uspoređeni s prijašnjim rezultatima biokemijskih analiza provedenih na klasu pšenice. Značajno jake korelacije između lista zastavičara i klasa u mjerenim parametrima nije bilo, što uz sortno-specifični odgovor upućuje i na tkivno-specifičan antioksidacijski odgovor.

Ključne riječi: pšenica, Fusarium culmorum, dušična gnojidba, oksidacijski stres, antioksidacijski odgovor

(Received on September 14, 2021; accepted on October 14, 2021 - Primljeno 14. rujna 2021.; prihvaćeno 14. listopada 2021.) 